\title{
DYNAMICS OF CHEMICAL COMPONENTS OF APPLES, TREATED WITH 1-METHYLCYCLOPROPENE AFTER HARVESTING
}

\author{
L. Khudik, O. Melnyk \\ Uman National University of Horticulture
}

\begin{tabular}{|c|c|}
\hline Key words: & ABSTRACT \\
\hline $\begin{array}{l}\text { 1-methylcyclopropene } \\
\text { Storage } \\
\text { Soluble solids } \\
\text { Titrated acidity } \\
\text { Ascorbic acid } \\
\text { Pre-cooling }\end{array}$ & \multirow{3}{*}{$\begin{array}{l}\text { The influence of post-harvest treatment of apples of early- } \\
\text { seeded varieties of "Calvill Snow" and "Spartan" with } \\
\text { ethylene inhibitor 1-methylcyclopropene (1-MCP, SmartFresh, } \\
\left.0.068 \mathrm{~g} \cdot \mathrm{m}^{-3}\right) \text { on the change of main chemical components of } \\
\text { apples during storage for six months in the fruit refrigerator } \\
\text { was investigated. The high efficiency of treating apples with } \\
\text { 1-MCS in order to slow down the loss of organic acids, } \\
\text { including ascorbic acid, maintaining the level of dry soluble } \\
\text { substances, as well as the dependence of changes in the } \\
\text { content of components of the chemical composition on the } \\
\text { duration of storage, were established. }\end{array}$} \\
\hline $\begin{array}{l}\quad \text { Article history: } \\
\text { Received 03.05.2017 } \\
\text { Received in revised form } \\
\text { 19.05.2017 } \\
\text { Accepted } 14.06 .2017\end{array}$ & \\
\hline $\begin{array}{l}\text { Corresponding author: } \\
\text { L. Khudik } \\
\text { E-mail: } \\
\text { npnuht@ukr.net }\end{array}$ & \\
\hline
\end{tabular}

DOI: $10.24263 / 2225-2924-2017-23-4-30$

\section{ДИНАМІКА КОМПОНЕНТІВ ХІМІЧНОГО СКЛАДУ ЯБЛУК, ОБРОБЛЕНИХ ПІСЛЯ ЗБИРАННЯ 1- МЕТИЛЦИКЛОПРОПЕНОМ}

\section{Л.М. Худік, О.В. Мельник \\ Уманський начіональний університет садівнищтва}

У статті досліджено вплив післязбиральної обробки яблук ранньозимових сортів Кальвіль сніговий і Спартан інгібітором етилену 1-метилииклопропеном (1-МЦП, преnарат «SmartFresh», 0,068 г/м ${ }^{3}$ ) на зміну основних компонентів хімічного складу плодів під час зберігання впродовж шести місяиів у фруктосховищі-холодильнику. Встановлено високу ефективність обробки яблук 1-МЦП щодо уповільнення втрат органічних кислот, у т. ч. аскорбінової, збереження рівня сухих розчинних речовин, а також залежність зміни вмісту компонентів хімічного складу від тривалості зберігання.

Ключові слова: 1-метилциклопропен, зберігання, сухі розчинні речовини, титрована кислотність, аскорбінова кислота, попереднє охолодження. 
Постановка проблеми. Вміст сухих розчинних речовин, органічних кислот, цукрів, вітамінів та їх співвідношення - основні біохімічні показники харчової цінності, що визначають смак плодів [1]. На початку зберігання вміст сухих розчинних речовин в яблуках зимових сортів зростає, далі знижується, а рівень органічних кислот здебільшого знижується за рахунок активного використання у дихальному газообміні [2].

Аскорбінова кислота (вітамін С) - природний антиоксидант [3], порівняно невисокий вміст якої в яблуках [4] знижується під час холодильного зберігання [5].

Збереження якості продукції й уповільнення достигання досягається післязбиральною обробкою яблук інгібітором етилену 1-метилциклопропеном (1-МЦП) [6], що забезпечує зниження втрат сухих розчинних речовин, органічних кислот [7], зокрема аскорбінової кислоти [8].

Аналіз останніх досліджень і публікацій. Післязбиральна обробка 1-МЦП уповільнює втрати органічних кислот в яблуках сорту Гала під час тривалого зберігання, проте суттєвого ефекту на збереження сухих розчинних речовин не виявлено [9]. В іншому дослідженні в плодах цього сорту зафіксовано суттєве уповільнення втрат сухих розчинних речовин та органічних кислот під дією 1-МЦП [10]. Позитивний вплив обробки 1-МЦП на зміну вмісту сухих розчинних речовин відсутній [11] або в оброблених 1-МЦП яблуках ранньозимового сорту Мекінтош він знижувався [12].

В іншому випадку вміст титрованих та аскорбінової кислот в яблуках сортів Гала та Голден і Ред Делішес впродовж 150-добового холодильного зберігання постійно знижувався, а рівень сухих розчинних речовин зростав [13]. Суттєвого впливу обробки 1-МЦП на зміну вмісту аскорбінової кислоти під час холодильного зберігання не виявлено [14].

Мета дослідження: оцінити вплив післязбиральної обробки яблук 1-метилциклопропеном на зміну вмісту в плодах сухих розчинних речовин, титрованих та аскорбінової кислот під час тривалого зберігання, а також залежність показників від тривалості зберігання.

Викладення основних результатів дослідження. Досліджували яблука сортів Кальвіль сніговий і Спартан ранньозимового строку достигання. Плоди 3 попереднім охолодженням за температури $5^{\circ} \mathrm{C}$ і без цього обробляли після збирання 1-метилциклопропеном (без обробки - контроль) та зберігали у фруктосховищі-холодильнику ФХ-770 Уманського НУС за температури $3 \pm 1^{\circ} \mathrm{C}$ і відносної вологості повітря 85-90\%. Температуру контролювали спиртовими термометрами, відносну вологість повітря - гігрометром.

У день збору половину продукції охолоджували за температури $5^{\circ} \mathrm{C}$ i відносної вологості повітря 85-90\% та обробляли 1-метилциклопропеном за рекомендацією виробника препарату SmartFresh (без обробки - контроль). Ящики з плодами ставили в газонепроникний контейнер 3 плівки завтовшки 200 мк, куди вміщували склянку 3 дистильованою водою і розрахованою на одиницю об’ єму дозою порошкоподібного препарату «SmartFresh» $\left(0,068 \mathrm{r} / \mathrm{m}^{3}\right)$. Циркуляцію повітря в контейнері здійснювали вентилятором. Іншу половину продукції обробляли одразу після збирання. 
Відбір проб і підготовку плодів до зберігання здійснювали за ГСТУ 01.137-160:2004. Фізико-хімічні показники яблук оцінювали після збирання та щомісячно впродовж шести місяців зберігання. Вміст сухих розчинних речовин визначали рефрактометром РПЛ-3М за ДСТУ ISO 2173:2007, вміст титрованих кислот - у перерахунку на яблучну — за ГОСТ 25555.0-82, аскорбінової кислоти - титрометричним методом за ГОСТ 24556-89 3 триразовим повторенням.

Статистичну обробку даних проводили 3 використанням програмних пакетів Excel-2010 i Statistika-10-En.

Сухі розчинні речовини. Встановлено, що вміст сухих розчинних речовин у плодах обох помологічних сортів зростав упродовж перших трьох місяців 3 подальшим зниженням під кінець зберігання (рис. 1). Рівень накопичення в яблуках сухих розчинних речовин під час зберігання суттєво залежав від його тривалості та післязбиральної обробки 1-МЦП, менше - від попереднього охолодження.

У середньому за роки досліджень, одразу після збирання яблука сорту Спартан, вирізнялися вищим на $0,7 \%$ від сорту Кальвіль сніговий вмістом сухих розчинних речовин (рис. 1).

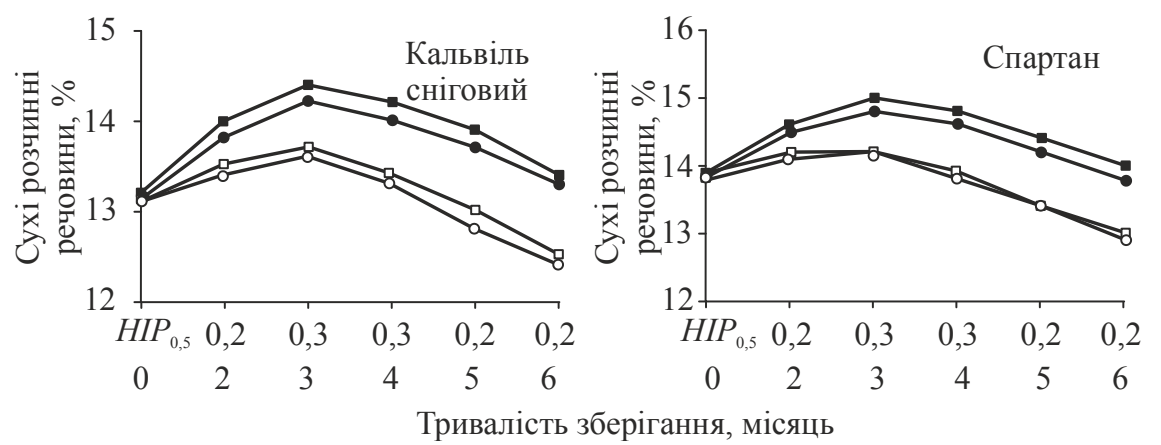

Рис. 1. Зміна вмісту сухих розчинних речовин під час зберігання яблук сортів Кальвіль сніговий (зліва) і Спартан (справа) (середнс для врожаю 2012-2013 рр.):

без попереднього охолодження: ○ — без обробки 1-МЦП, • - оброблено 1-МЦП;

3 попереднім охолодженням: $\square$ - без обробки 1-МЦП, - - оброблено 1-МЦП

Тенденція переважання показника збереглася у процесі зберігання яблук цього помологічного сорту з обробкою 1-МЦП і без неї. Порівняно 3 необробленими плодами, післязбиральна обробка 1-МЦП суттєво уповільнила втрати сухих розчинних речовин під час тривалого зберігання.

Після двомісячного зберігання найвищий - 14,1-14,2\% - вміст сухих розчинних речовин зафіксовано в необроблених яблуках сорту Спартан.

Після чотирьох — П'яти місяців зберігання зафіксовано більш інтенсивне зниження рівня сухих розчинних речовин у плодах, оброблених 1-МЦП та без обробки. Проте післязбиральна обробка забезпечила вищий на $0,9-1,2 \%$ показник яблук сорту Кальвіль сніговий і на $0,9-1,1 \%$ - сорту Спартан. Залежність описується оберненими рівняннями регресії квадратичного типу із високими коефіцієнтами детермінації (див. табл.). 
У середньому за роки досліджень загальні втрати сухих розчинних речовин необробленими плодами сорту Кальвіль сніговий і Спартан на кінець шестимісячного зберігання, порівняно 3 початковим вмістом, становили відповідно 4,6-5,3 та $6,5 \%$, в той час як післязбиральна обробка 1-МЦП забезпечила вищий відповідно на 1,5 та 0,4\% показник.

Органічні кислоти. Встановлено значне уповільнення втрат органічних кислот яблуками 3 післязбиральною обробкою 1-МЦП одразу після зберігання (рис. 2).

Подальше зберігання в середньому урівноважило інтенсивність зниження титрованої кислотності оброблених 1-МЦП та необроблених яблук сорту Кальвіль сніговий з деяким перевищенням в необроблених плодах. Подібна тенденція зміни вмісту титрованих кислот характерна також для яблук сорту Спартан упродовж всього періоду зберігання.

Після чотиримісячного зберігання в яблуках з післязбиральною обробкою 1-МЦП сортів Кальвіль сніговий і Спартан вищий відповідно на $0,21-0,22$ та $0,10 \%$ рівень титрованих кислот, порівняно з необробленими плодами.

На кінець шести місяців зберігання рівень титрованих кислот в оброблених 1-МЦП яблуках сорту Кальвіль сніговий на $0,19-0,20 \%$ вищий, порівняно $з$ необробленими плодами, що в 2,2-2,4 раза перевищує показник сорту Спартан.

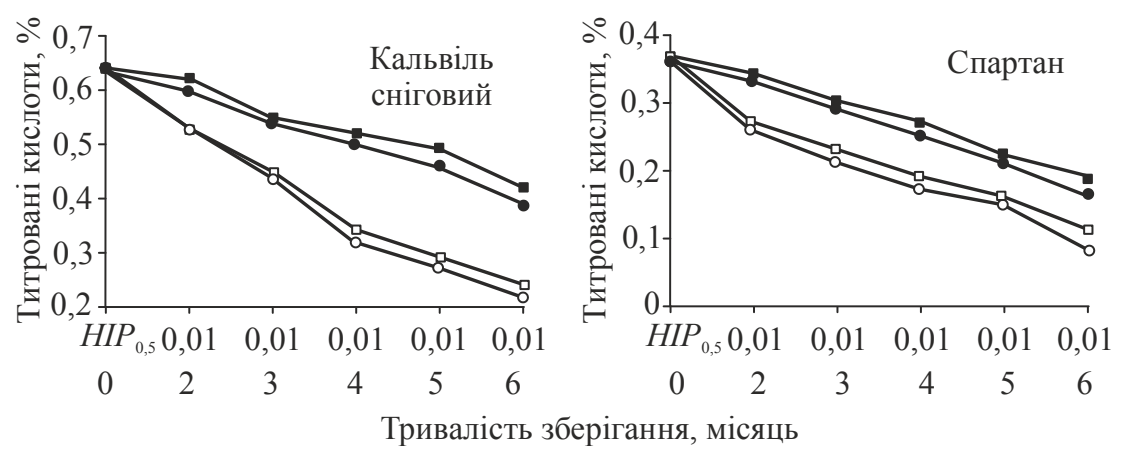

Рис. 2. Зміна вмісту титрованих кислот під час зберігання яблук сортів Кальвіль сніговий (зліва) і Спартан (справа) (середнс для врожаю 2012-2013 рр.):

без попереднього охолодження: ○ — без обробки 1-МЦП, •- оброблено 1-МЦП;

3 попереднім охолодженням: - - без обробки 1-МЦП, - оброблено 1-МЦП

Аскорбінова кислота. Зміна вмісту аскорбінової кислоти залежала в основному від тривалості зберігання яблук (рис. 3).

Порівняно з необробленими плодами, післязбиральна обробка 1-МЦП на $54,2-64,7 \%$ уповільнила зниження вмісту аскорбінової кислоти в плодах сорту Спартан і в 2,7-3,1 раза слабше в яблуках сорту Кальвіль сніговий після двохмісячного зберігання. Однак, подальше зберігання зумовило нерівномірне зниження показника оброблених плодів.

Порівняно з плодами без обробки, для яблук обох сортів без попереднього охолодження характерне в $1,8-4,2$ раза інтенсивніше зниження вмісту аскорбінової кислоти на кінець трьохмісячного зберігання. 
Суттєву втрату аскорбінової кислоти на кінець п’яти місяців зберігання встановлено для яблук сортів Роял Гала $(42,9 \%)$, Мондіал Гала $(41,3)$, Голден Делішес $(38,1)$ та Ред Делішес $(27,1 \%)$ [13].

Післязбиральна обробка 1-МЦП яблук сортів Кальвіль сніговий і Спартан забезпечила лише на $0,27-0,41$ та $0,29-0,37$ мг/100 г вищий залишковий рівень аскорбінової кислоти на кінець шестимісячного зберігання.

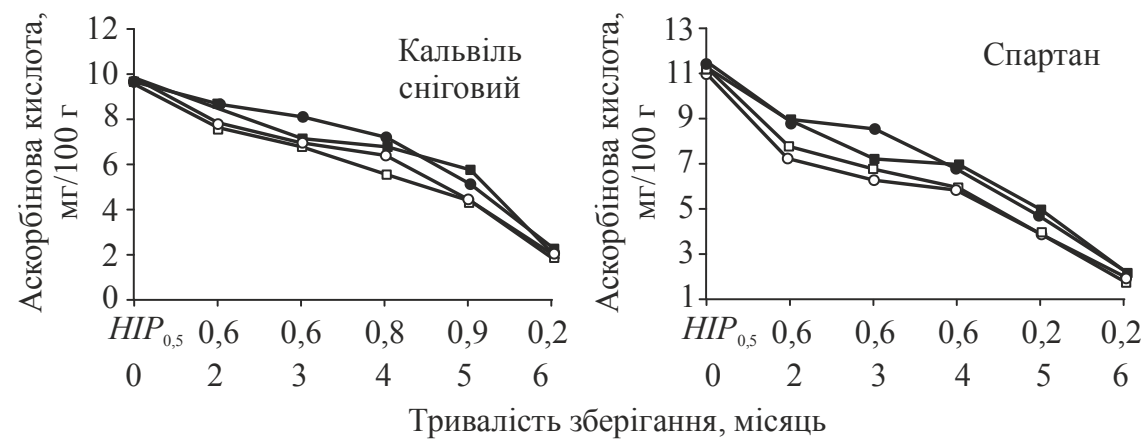

Рис. 3. Зміна вмісту аскорбінової кислоти під час зберігання яблук сортів Кальвіль сніговий (зліва) і Спартан (справа) (середнс для врожаю 2012-2013 рp.): без попереднього охолодження о - без обробки 1-МЦП, • - оброблено 1-МЦП; 3 попереднім охолодженням: $\square-$ без обробки 1-МЦП, п- оброблено 1-МЦП

У середньому за роки досліджень, післязбиральна обробка яблук 1-МЦП забезпечила на кінець шестимісячного зберігання на $2,7-4,2 \%$ вищий вміст аскорбінової кислоти в плодах сорту Кальвіль сніговий та на 2,3-3,4\% в яблуках сорту Спартан.

Залежність досліджуваних показників від тривалості зберігання яблук криволінійна здебільшого обернена із сильним чи навіть повним взаємозв'язком (табл.).

Таблиия Залежність вмісту компонентів хімічного складу від тривалості зберігання яблук

\begin{tabular}{|c|c|c|c|}
\hline 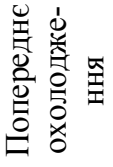 & $\begin{array}{c}\text { Доза } \\
\text { Смарт- } \\
\text { Фреф, г/м }\end{array}$ & Показник & $\begin{array}{c}\text { Рівняння регресії } \\
\text { з коефіцієнтом детермінації } \mathrm{R}^{2}\end{array}$ \\
\hline- & 2 & 3 & 4 \\
\hline \multicolumn{4}{|c|}{ Кальвіль сніговий } \\
\hline \multirow{6}{*}{ 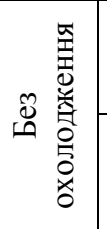 } & \multirow{3}{*}{0} & Сухі розчинні речовини & $y=-0,11 x^{2}+0,63 x+12,6 ; R^{2}=0,96$ \\
\hline & & Титровані кислоти & $y=0,01 x^{2}-0,14 x+0,8 ; R^{2}=0,99$ \\
\hline & & Аскорбінова кислота & $y=-0,14 x^{2}-0,49 x+10 ; R^{2}=0,97$ \\
\hline & \multirow{3}{*}{0,068} & Сухі розчинні речовини & $y=-0,15 x^{2}+1,05 x+12,3 ; R^{2}=0,95$ \\
\hline & & Титровані кислоти & $y=-0,001 x^{2}-0,04 x+0,7 ; R^{2}=0,99$ \\
\hline & & Аскорбінова кислота & $y=-0,27 x^{2}+0,48 x+9,2 ; R^{2}=0,99$ \\
\hline \multirow{6}{*}{ 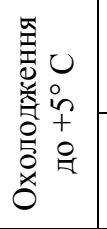 } & \multirow{3}{*}{0} & Сухі розчинні речовини & $y=-0,12 x^{2}+0,73 x+12,5 ; R^{2}=0,97$ \\
\hline & & Титровані кислоти & $y=0,01 x^{2}-0,13 x+0,8 ; R^{2}=0,99$ \\
\hline & & Аскорбінова кислота & $y=-0,08 x^{2}-0,88 x+10,2 ; R^{2}=0,98$ \\
\hline & \multirow{3}{*}{0,068} & Сухі розчинні речовини & $y=-0,17 x^{2}+1,18 x+12,3 ; R^{2}=0,96$ \\
\hline & & Титровані кислоти & $y=-0,002 x^{2}-0,03 x+0,7 ; R^{2}=0,98$ \\
\hline & & Аскорбінова кислота & $y=-0,19 x^{2}-0,02 x+9,5 ; R^{2}=0,94$ \\
\hline
\end{tabular}




\begin{tabular}{|c|c|c|c|}
\hline & & & Продовження табл. \\
\hline- & 2 & 3 & 4 \\
\hline & & Cnap & \\
\hline & & Сухі розчинні речовини & $y=-0,11 x^{2}+0,55 x+13,4 ; R^{2}=0,97$ \\
\hline 㭊 & 0 & Титровані кислоти & $y=0,01 x^{2}-0,08 x+0,4 ; R^{2}=0,97$ \\
\hline m & & Аскорбінова кислота & $y=0,08 x^{2}-2,15 x+12,4 ; R^{2}=0,94$ \\
\hline 1 & & Сухі розчинні речовини & $y=-0,15 x^{2}+x+13 ; R^{2}=0,94$ \\
\hline కo & 0,068 & Титровані кислоти & $y=-0,002 x^{2}-0,03 x+0,4 ; R^{2}=0,99$ \\
\hline & & Аскорбінова кислота & $y=-0,16 x^{2}-0,57 x+11,6 ; R^{2}=0,98$ \\
\hline & & Сухі розчинні речовини & $y=-0,1 x^{2}+0,48 x+13,6 ; R^{2}=0,97$ \\
\hline 在 & 0 & Титровані кислоти & $y=0,01 x^{2}-0,08 x+0,4 ; R^{2}=0,98$ \\
\hline in & & Аскорбінова кислота & $y=0,07 x^{2}-2,23 x+13,1 ; R^{2}=0,96$ \\
\hline tro & & Сухі розчинні речовини & $y=-0,16 x^{2}+1,1 x+13 ; R^{2}=0,94$ \\
\hline$\stackrel{1}{*}$ & 0,068 & Титровані кислоти & $y=-0,001 x^{2}-0,03 x+0,4 ; R^{2}=0,99$ \\
\hline & & Аскорбінова кислота & $y=-0,06 x^{2}-1,25 x+12,3 ; R^{2}=0,96$ \\
\hline
\end{tabular}

Менш тісні залежності сухих розчинних речовин виявлено для плодів обох досліджуваних сортів з обробкою 1-МЦП.

Взаємозалежність титрованих кислот обернена для оброблених 1-МЦП яблук та пряма - для плодів обох помологічних сортів без обробки.

Взаємозалежність аскорбінової кислоти обернена, за винятком необроблених плодів сорту Спартан. Найбільш тісні залежності цього показника зафіксовано для оброблених 1-МЦП яблук обох сортів без попереднього охолодження, найменш тісні - для неохолоджених плодів сорту Спартан без обробки та попередньо охолоджених сорту Кальвіль сніговий з обробкою 1-МЦП.

\section{Висновки}

Післязбиральна обробка 1-МЦП яблук ранньозимових сортів Кальвіль сніговий і Спартан забезпечує на кінець шести місяців холодильного зберігання відповідно на 1,5 та $0,4 \%$ вищий залишковий вміст сухих розчинних речовин на противагу $4,6-6,5 \%$ загальних їх втрат, порівняно 3 початковим вмістом, необробленими плодами; у 1,8 та $1,7-2,0$ раза вищий залишковий рівень титрованих кислот; лише на $2,7-4,2$ та $2,3-3,4 \%$ вищий залишковий рівень аскорбінової кислоти на кінець шестимісячного зберігання та $є$ ефективною для покращення збереженості її впродовж п'яти місяців зберігання у холодильнику.

Залежність зміни вмісту основних компонентів хімічного складу яблук обох помологічних сортів від тривалості зберігання переважно обернена.

Подяка фірмі «Агрофреш» (Польща) за надання препарату SmartFresh для досліджень.

\section{Література}

1. Nistor O.-V., Botez E., Mocanu G.-D., Andronoiu D.-G., Macovei V.M. Study of the apple parameters'variation during refrigeration Storage // Journal of Agroalimentary Processes and Technologies. - 2011. - Vol. 17. — \# 4. - P. 439- 444.

2. Ghafir S. A.M., Gadalla S.O., Murajei B.N., El-Nady M.F. Physiological and anatomical comparison between four different apple cultivars under cold-storage conditions // Afri. J. of Pl. Sci. - 2009. — \# 3. - P. 133-138. 
3. Lata B. Relationship between apple peel and the whole fruit antioxidant content: year and cultivar variation // J. Agric. Food Chem. - 2007. — \# 55. — P. 663-671.

4. Lee K.W., Kim Y.J., Kim D.O., Lee H.J., Lee C.Y. Major phenolics in apple and their contribution to the total antioxidant capacity // J. Agric. Food Chem. - 2003. — \# 51. P. $6516-6520$.

5. Hayat I., Masud T., Rathore H.A. Effect of coating and wrapping materials on the shelf life of apple // Internet J. Food Safety. - 2003. — \# 5. - P. 24-34.

6. Park Y.-M. 1-MCP application for horticultural commodities in Korea: practical potential and future task // Hort. Environ. Biotechnol. — 2012. - Vol. 53. - \# 6. - P. 441- 446.

7. Argenta L.C., Fan X., Mattheis J.P. Responses of 'Golden Delicious' apples to 1-MCP applied in air or water // HortScience. - 2007. — Vol. 42. — \# 7. — P. 1651-1655.

8. Moor U., Karp K., Poldma P., Starast M. Effect of 1-MCP treatment on apple biochemical content and physiological disorders // Acta Agronomica Hungarica. — 2007. - Vol. 55. — № 1. P. $61-70$.

9. Wawrzynczak A., Jozwiak Z.B., Rutkowski K.P. The influence of storage conditions and 1-MCP treatment on ethylene evolution and fruit quality in 'Gala' apples // Vegetable crops research bulletin. - 2007. - Vol. 66. - P. 187-196.

10. Bai J., Baldwin E.A., Goodner K.L., Mattheis J.P., Brecht J.K. Response of four apple cultivars to 1-methylcyclopropene treatment and controlled atmosphere storage // HortScience. 2005. — Vol. 40. — \# 5. - P. 1534-1538.

11. DeLong J.M., Prange R.K., Harrison P.A. The influence of 1-methylcyclopropene on "Cortland" and "McIntosh" apple quality following long-term storage // HortSci. — 2004. Vol. 39. - P. 1062-1065.

12. Watkins C.B., Nock J.F., Whitaker B.D. Responses of early, mid and late seasone apple cultivars to postharvest application of 1-methylcyclopropene (1-MCP) under air controlled atmosphere storage conditions // Postharvest biol. Technol. - 2000. - Vol. 19. - P. 17-32.

13. Jan I., Rab A. Influence of storage duration on physiko-chemical changes in fruit of apple cultivars // The Journal of Animal \& Plant Sciences. - 2012. — Vol. 22. — \# 3. P. 708-714.

14. Bizjak J., Slatnar A., Stampar F., Veberic R. Changes in quality and biochemical parameters in "Idared" apples during prolonged shelf life and 1-MCP treatment // Food Sci. Technol. - 2012. - Vol. 18. - \# 6. - P. 569-577.

15. Serdyuk M., Velichko I., Priss O., Danchenko O., Kurcheva L., Baiberova S. Substantiation of the choice of optimal concentrations of active ingredients of the antioxidant composition for fruit treatment before storage // Technology audit and production reserves. - 2017. Vol. 35. - \# 3/3. - P. $44-49$.

16. Іванченко В.Й. Деякі біохімічні показники яблук при довгостроковому зберіганні за обробки їх антиоксидантами / В.Й. Іванченко, О.П. Прісс, В.В. Калитка // Таврійський науковий вісник. - Херсон, 1999. - Випуск 12. - С. 114-118. 